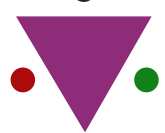

IJCRR

Section: Healthcare Sci. Journal Impact Factor: 6.1 (2018) ICV: 90.90 (2018)

(c) (i) (3)

Copyright@IJCRR

\section{Quality of Life and Their Effects on Employment of Rural Diabetic Foot Ulcer Patients in Central India}

\section{Swagata Brahmachari ${ }^{1}$, SK Khairul Enam ${ }^{2}$, Kshitij Gupta ${ }^{3}$, Vaishali Bhagat ${ }^{4}$}

\author{
'Associate Professor, Department of general Surgery, AllMS Bhopal, Madhya Pradesh, India; 'Associate Professor, Department of \\ General Surgery, Shri Shankaracharya Medical College, Bhilai, Durg, Chhattisgarh, India; ${ }^{3}$ Assistant Professor, Department of General \\ Surgery, Shri Shankaracharya Medical College, Bhilai, Durg, Chhattisgarh, India; ${ }^{4}$ Assistant Professor, Department of General \\ Surgery, Shri Shankaracharya Medical College, Bhilai, Durg, Chhattisgarh, India.
}

\title{
ABSTRACT
}

Background: Evidence on HRQL, employment-related factors and expenditure related factor is extremely rare in central India particularly among rural diabetic population.

Objectives: This study was performed to measure the effects and health-related quality of life among patients suffering from healed and unhealed diabetic foot ulcer in the central Indian rural population.

Method: This was an observational and cross-sectional survey among 118 diabetic foot ulcer patients of either sex were selected randomly from the patients visiting the routine Surgery OPD of tertiary care centres. A pre-tested structured interview proforma was used to collect demographic, social, familial, treatment-related factors, employment and expenditure details. The 29 types of question item DFS- SF was used to evaluate the health-related quality of life among the same diabetic patients in rural population. For the economic loss, this was calculated by the total value of man-days lost in case of the employed population.

Results: The mean \pm SD of total HRQL score for the healed group was $74.86 \pm 12.11$, and the unhealed group was $59.92 \pm$ 15.41. The difference between the mean scores for ulcer duration and sex was $16.75(95 \% \mathrm{Cl}=[-22.66,-10.81])$. The median value for the total economic loss was 26000 INR (range of 450 to 42000 INR).

Conclusion: The mean HRQL score was statistically significant when compared between healed and unhealed groups. There is a gross economic burden imposed on the family by diabetic foot ulcer which needs greater attention. A multidisciplinary approach is needed to reduce the social and economic consequences of diabetic Mellitus causing severe foot ulcers.

Key Words: Diabetic foot ulcer, HRQL score, Rural

\section{INTRODUCTION}

Diabetes mellitus is one of the major chronic non-communicable diseases which have attained the status of a major epidemic in newly industrialized and developing nations. India is the second-largest contributor to the world's diabetic load after China with a prevalence of $8.9 \%{ }^{1}$

Diabetes is a chronic disease that occurs when the pancreas does not produce enough insulin or the insulin produced is not effectively used causing hyperglycaemia. ${ }^{2}$ Uncontrolled blood glucose level for a longer set of time can cause irreversible harm to the circulatory system, eyes, kidneys and nerves leading to cardiovascular diseases, vision loss, nephritis and lower limb loss. ${ }^{3}$

The complications due to diabetes affect the foot in $>30 \%$ of diabetic patients over 40 years of age. ${ }^{2}$ According to the guidelines of International Working Group (IWGDF), a diabetic foot ulcer (DFU) is a full-thickness infective nonhealing ulcer over foot involving deeper tissue along with associated neuropathy, vasculopathy and bony changes located below the ankle in a diabetic patient. ${ }^{3}$ DFU patients are 15 times more at risk of undergoing a lower-extremity amputation and account for $85 \%$ of non-traumatic lower-limb amputations. ${ }^{4}$ Indian diabetic patients of rural area are more prone to DFU, the prevalence being 5.3-13.6\% due to lack of knowledge of foot-care and proper footwear and habit of barefoot walking. ${ }^{4}$

Diabetes and its complication, especially DFU affects the quality of life in the physical health and daily activities, leisure, social and psycho-emotional as there is reduced mobility, difficulty in performing daily activities in the home and work leading to reduced productivity. ${ }^{10}$

\section{Corresponding Author:}

Dr. Vaishali Bhagat, Department of General Surgery, Shri Shankaracharya Medical College, Junwani, Bhilai, Durg, Chhattisgarh-490020, India; Email: panhealth121013@gmail.com

ISSN: 2231-2196 (Print)

Received: 20.06 .2020
ISSN: 0975-5241 (Online)

Revised: 30.07 .2020
Accepted: 10.08 .2020
Published: 08.09 .2020 


\section{AIMS AND OBJECTIVE}

1. To study the impact of foot ulcer on health-related quality of life (HRQL) and employment-related factors among healed as well as unhealed diabetic foot ulcer patients

2. To validate the diabetic foot ulcer scale short form (DFS - SF) in the rural population of central India.

\section{MATERIALS AND METHODS}

The present study is a multi-centric, cross-sectional study carried out in diabetic patients attending three diabetic centres of medical college and tertiary care settings during the period from 1st June to 30th September 2019. A total of 118 diabetic foot ulcer patients were included in the study with written consent.

\section{Inclusion criteria:}

1. Patients aged between 18 years and 60 years with diabetic foot ulcer diagnosed for a minimum of one year with written consent.

\section{Exclusion criteria:}

1. Patients with severe physical or cognitive impairments

2. Patient not willing to give consent was excluded from the study.

The validation of the Hindi version of the Diabetic Foot Ulcer Scale-Short Form [DFS- SF] questionnaire was done as an initial step to use the scale in the tertiary care setting. We interviewed participants with two different scales (diabetic foot ulcer scale short form (DFS - SF), which was developed by MAPI Trust, the standardized general quality of life questionnaire to measure the quality of life for validation.

After obtaining written consent, all the 118 patients included in the study were interviewed using the Hindi version of Diabetic Foot Ulcer Scale-Short Form [DFS SF] questionnaire to assess the quality of life.

The thorough case history was taken related to understand the knowledge of the patients about their disease condition, change in their daily wedges status and bad effect on their working capacity and the working pattern was taken into consideration. Major problems were faced by the patients, after the occurrence of foot ulcer, expenditure pattern, health-seeking behaviour, and changes which occurred in their family life. A key informant interview with the moderator was carried out to understand the various management tactics used for the care of foot ulcer. Deductive themes were generated after the questionnaire, using the guidelines as per given for formative research.
At first, all the elucidating insights were determined for all the factors gathered. The composite variable 'financial status' was made from the information gathered on the announced month to month family unit use and the family unit resources possessed by the examination members. We gathered the complete example into two (recuperated and unhealed) in light of the status of the wound and afterwards looked at the significant attributes of the gatherings. The normal of the subscale scores were begat as 'Absolute personal satisfaction' to get a general image of the elements related to HRQL among foot ulcer patients.

Our essential goal was to analyze the HRQL in the two gatherings of patients, for example, mended and unhealed. We utilized examination of covariance (ANCOVA) utilizing the ' $1 \mathrm{~m}$ ' work in R. ANCOVA expect that the relapse slants of consistent result variable was different but parallel in the two groups after adjusting for other covariates.

\section{RESULTS}

Table I shows Interior consistency was evaluated as a proportion of unwavering quality to quantify routine working capacity in every one of the five spaces of DFS SF and Cronbach's coefficient alpha assessed.

\section{Table I: Internal consistency for different domains of} the score $(n=49)$

\begin{tabular}{|c|c|c|c|}
\hline \multirow[t]{2}{*}{ Domain } & \multirow{2}{*}{$\begin{array}{l}\text { Number } \\
\text { of Items in } \\
\text { the scale }\end{array}$} & \multicolumn{2}{|c|}{ Internal Consistency } \\
\hline & & $\begin{array}{c}\text { Average Item } \\
\text { Correlation }\end{array}$ & $\begin{array}{c}\text { Cronbach's } \\
\text { Alpha }(\alpha)\end{array}$ \\
\hline Leisure & 5 & 0.50 & 0.84 \\
\hline Physical health & 5 & 0.23 & 0.60 \\
\hline Daily Activities & 5 & 0.43 & 0.79 \\
\hline Emotions & 10 & 0.21 & 0.72 \\
\hline Treatment & 4 & 0.30 & 0.63 \\
\hline
\end{tabular}

Table II shows the correlation matrix with SF 36 Vs DFS-SF. ['\#' mention a strong correlation between the above-mentioned scales]. 
Table II: Correlation matrix with SF 36 Vs DFS-SF $(n=49)$

\begin{tabular}{|c|c|c|c|c|c|c|c|c|}
\hline \multirow[t]{2}{*}{ DFS SF Scale } & \multicolumn{8}{|c|}{$\mathrm{SF}_{36} \mathrm{~V}_{2}$ Scale } \\
\hline & 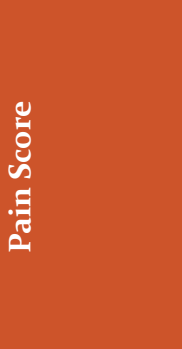 & 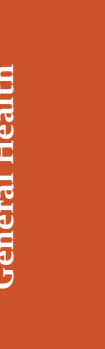 & 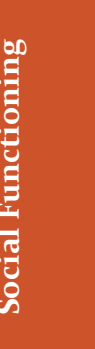 & 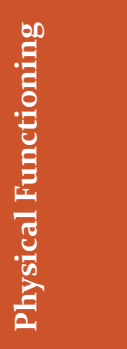 & 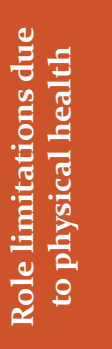 & 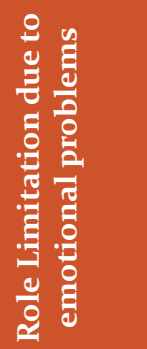 & 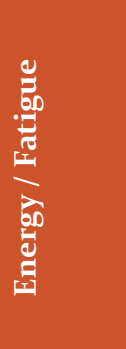 & 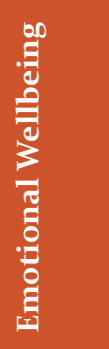 \\
\hline Leisure & 0.38 & 0.40 & 0.44 & $0.59^{\#}$ & 0.24 & 0.28 & 0.22 & 0.37 \\
\hline $\begin{array}{l}\text { Physical } \\
\text { Health }\end{array}$ & $0.59^{\#}$ & $0.62^{\#}$ & 0.29 & 0.35 & $0.54^{\#}$ & $0.58^{\#}$ & $0.6 \mathrm{o}^{\#}$ & $0.58^{\#}$ \\
\hline $\begin{array}{l}\text { Daily } \\
\text { Activities }\end{array}$ & $0.52^{\#}$ & 0.45 & 0.37 & $0.63^{\#}$ & 0.36 & 0.43 & 0.39 & 0.39 \\
\hline Emotions & 0.48 & 0.47 & 0.35 & $0.56^{\#}$ & 0.40 & $0.57^{\#}$ & 0.43 & $0.65^{\#}$ \\
\hline Treatment & $0.55^{\#}$ & 0.39 & 0.44 & $0.57^{\#}$ & 0.30 & 0.39 & 0.30 & $0.64^{\#}$ \\
\hline
\end{tabular}

Table II shows the correlation matrix with SF 36 Vs DFS-SF. ['\#' denotes the domains which showed a strong correlation between the above-mentioned scales.

Table III shows that 87 (73.7\%) patients were observed in the unhealed group and $31(26.3 \%)$ were in the healed group. 58 $(49.2 \%)$ had a one-time history of ulcer.

Table III: Disease characteristics of the study sample $(\mathrm{n}=118)$

\begin{tabular}{lcc} 
Variables & Categories & Frequency $(\%)$ \\
Status of wound & Healed & $31(26.3)$ \\
& Unhealed & $87(73.7)$ \\
$\begin{array}{l}\text { Medication discontinued } \\
\text { at any point in time }\end{array}$ & Yes & $39(33.1)$ \\
History of foot ulcer & One time & $79(66.9)$ \\
& Two times & $42(35.6)$ \\
& Three times & $7(5.9)$ \\
& More than & $11(9.3)$ \\
& three times & \\
\hline
\end{tabular}

Table IV: Socio-demographic and clinical characteristics in the two groups

\begin{tabular}{lcc|}
\hline Indicators & $\begin{array}{c}\text { Healed ulcer } \\
(\mathrm{n}=31)\end{array}$ & $\begin{array}{c}\text { Unhealed ulcer } \\
(\mathrm{n}=87)\end{array}$ \\
\hline $\begin{array}{l}\text { Mean age in years } \\
\text { (SD) }\end{array}$ & $57.52(8.4)$ & $57.71(7.5)$ \\
\hline
\end{tabular}

$\operatorname{Sex}(\%)$

$\begin{array}{lll}\text { Female } & 38.70 & 31.00 \\ \text { Male } & 61.30 & 69.00\end{array}$

Education (\%)

Upper primary

$35 \cdot 50 \quad 13.80$

High school

58.10

63.20

Higher secondary

3.20

9.20

Higher education

3.20

13.80

\section{Socio economic status}

(\%)

Low

45.20

32.20

Medium

38.70

28.70

High

16.10

39.10

$\begin{array}{lll}\begin{array}{l}\text { Mean DM duration in } \\ \text { years (SD) }\end{array} & 13.61(6.41) & 15.76(7.25) \\ \text { Mean ulcer duration } & 9.48(8.95) & 6.44(6.52)\end{array}$
in months (SD)

Table IV shows that socio-demographic and clinical characteristics in the two groups.

Table V shows significant results of two factors ANOVA for Subscale 1 - Leisure score. 
Table V: Results of two factor ANOVA for Subscale 1 - Leisure score, n (118)

\begin{tabular}{|c|c|c|c|c|}
\hline Variables & Mean \pm SD & Mean \pm SD & $\begin{array}{l}\text { Adj p values } \\
\text { for indicator } \\
\text { variable }\end{array}$ & $\begin{array}{l}\text { Adj p values } \\
\text { for wound } \\
\text { status }\end{array}$ \\
\hline Wound status & $\begin{array}{c}\text { Healed } \\
73.07 \pm 20.88(31)\end{array}$ & $\begin{array}{c}\text { Unhealed } \\
45.23 \pm 22.03(87)\end{array}$ & & \\
\hline $\begin{array}{l}\text { Sex } \\
\text { Female }\end{array}$ & $65.42 \pm 19.48(12)$ & $46.30 \pm 24.83(27)$ & 0.57 & $0.00^{*}$ \\
\hline Male & $77.90 \pm 20.77(19)$ & $44.75 \pm 20.86(60)$ & & \\
\hline $\begin{array}{l}\text { Age } \\
\leq 60 \text { yrs }\end{array}$ & $74 \cdot 38 \pm 25 \cdot 29(16)$ & $43.28 \pm 21.84(58)$ & 0.42 & $0.00^{*}$ \\
\hline$>60$ yrs & $71.67 \pm 15.66(15)$ & $49.14 \pm 22.28(29)$ & & \\
\hline $\begin{array}{l}\text { SES_groups } \\
\text { Low }\end{array}$ & $75.36 \pm 21.26(14)$ & $40.54 \pm 25.83(28)$ & 0.48 & $0.00^{*}$ \\
\hline $\begin{array}{l}\text { Medium } \\
\text { High }\end{array}$ & $\begin{array}{l}70.42 \pm 21.79(12) \\
73.00 \pm 21.39(5)\end{array}$ & $\begin{array}{l}49.00 \pm 23.23(25) \\
46.32 \pm 17.20(34)\end{array}$ & & \\
\hline $\begin{array}{l}\text { Education_groups } \\
\text { Upper Primary }\end{array}$ & $73.18 \pm 21.36(11)$ & $42.08 \pm 25.09(12)$ & 0.75 & $0.00^{*}$ \\
\hline $\begin{array}{l}\text { High School Higher Secondary } \\
\text { Higher education }\end{array}$ & $\begin{array}{c}\text { 71.11 } \pm 21.46(18) \\
95.00 \pm N A(1) \\
85.00 \pm N A(1)\end{array}$ & $\begin{array}{c}45.09 \pm 22.96(55) \\
50.63 \pm 9.43(8) \\
45.42 \pm 22.10(12)\end{array}$ & & \\
\hline
\end{tabular}

Table VI: Results of two factors ANOVA for Subscale 2 - Physical health score

\begin{tabular}{|c|c|c|c|c|}
\hline Variables & Mean \pm SD & Mean \pm SD & $\begin{array}{l}\text { Adj p } \\
\text { Values }\end{array}$ & $\begin{array}{l}\text { Adj p values } \\
\text { for wound status }\end{array}$ \\
\hline Wound status & $\begin{array}{c}\text { Healed } \\
73.23 \pm 18.28(31)\end{array}$ & $\begin{array}{c}\text { Unhealed } \\
63.68 \pm 19.64(87)\end{array}$ & & \\
\hline $\begin{array}{l}\text { Sex } \\
\text { Female }\end{array}$ & $72.5 \pm 14.22(12)$ & $57.22 \pm 19.03(27)$ & 0.06 & $0.02^{*}$ \\
\hline Male & $73.68 \pm 20.81(19)$ & $66.58 \pm 19.37(60)$ & & \\
\hline $\begin{array}{l}\text { Age } \\
\leq 60 \mathrm{yrs}\end{array}$ & $78.44 \pm 15 \cdot 57(16)$ & $64 \cdot 31 \pm 19 \cdot 75(58)$ & 0.23 & $0.02^{*}$ \\
\hline$>60 \mathrm{yrs}$ & $67.67 \pm 19.81(15)$ & $62.41 \pm 19.71(29)$ & & \\
\hline $\begin{array}{l}\text { SES groups } \\
\text { Low }\end{array}$ & $70.00 \pm 22.27(14)$ & $60.54 \pm 19.97(28)$ & 0.17 & $0.02^{*}$ \\
\hline $\begin{array}{l}\text { Medium } \\
\text { High }\end{array}$ & $\begin{array}{c}75.00 \pm 15.23(12) \\
78.00 \pm 13.51(5)\end{array}$ & $\begin{array}{l}64.00 \pm 22.31(25) \\
66.03 \pm 17.40(34)\end{array}$ & & \\
\hline $\begin{array}{l}\text { Education groups } \\
\text { Upper Primary }\end{array}$ & $60.46 \pm 21.03(11)$ & $54.17 \pm 19.64(12)$ & $0.01^{*}$ & $0.02^{*}$ \\
\hline $\begin{array}{l}\text { High School Higher Secondary } \\
\text { Higher education }\end{array}$ & $\begin{array}{c}79.17 \pm 12.28(18) \\
85.00 \pm N A(1) \\
95.00 \pm N A(1)\end{array}$ & $\begin{array}{c}64.27 \pm 20.33(55) \\
69.38 \pm 18.21(8) \\
66.67 \pm 16.00(12)\end{array}$ & & \\
\hline
\end{tabular}

Table VI shows significant results of two factors ANOVA for Subscale 2 - Physical health score 
Table VII: Results of two factors ANOVA for Subscale 3 - Daily activities score

\begin{tabular}{|c|c|c|c|c|}
\hline $\begin{array}{l}\text { Variables } \\
\text { Wound status }\end{array}$ & $\begin{array}{l}\text { Mean } \pm \text { SD } \\
\text { Healed }\end{array}$ & $\begin{array}{l}\text { Mean } \pm \text { SD } \\
\text { Unhealed }\end{array}$ & Adj p values & $\begin{array}{l}\text { Adj p values for wound } \\
\text { status }\end{array}$ \\
\hline Sex & & & 0.13 & $0.00^{*}$ \\
\hline Female & $68.75 \pm 9.08(12)$ & $55.93 \pm 21.62(27)$ & & \\
\hline Male & $80.26 \pm 16.20(19)$ & $59.08 \pm 18.81(60)$ & & \\
\hline Age & & & 0.62 & $0.00^{*}$ \\
\hline$\leq 60$ yrs & $75 \cdot 31 \pm 12.31(16)$ & $57 \cdot 41 \pm 17.58(58)$ & & \\
\hline$>60 \mathrm{yrs}$ & $76.33 \pm 17.57(15)$ & $59 \cdot 48 \pm 23.54(29)$ & & \\
\hline SES_groups & & & 0.00 & $0.00^{*}$ \\
\hline Low & $71.07 \pm 14.96(14)$ & $51.25 \pm 18.49(28)$ & & \\
\hline Medium & $77.92 \pm 15.15(12)$ & $58.80 \pm 20.27(25)$ & & \\
\hline High & $84.00 \pm 10.84(5)$ & $63.24 \pm 18.99(34)$ & & \\
\hline Education_groups & & & 0.13 & $0.00^{*}$ \\
\hline Upper Primary & $70.00 \pm 17.89(11)$ & $52.92 \pm 16.30(12)$ & & \\
\hline High School & $77.78 \pm 12.27(18)$ & $57.18 \pm 20.45(55)$ & & \\
\hline Higher Secondary & $90.00 \pm N A(1)$ & $67.50 \pm 19.64(8)$ & & \\
\hline Higher education & $90.00 \pm \mathrm{NA}(1)$ & $61.25 \pm 18.60(12)$ & & \\
\hline
\end{tabular}

Table VII shows significant results of two factors ANOVA for Subscale 3 - Daily activities score

Table VIII: Results of two factors ANOVA for Subscale 4 - Emotions score, n (118)

\begin{tabular}{|c|c|c|c|c|}
\hline Variables & Mean \pm SD & Mean \pm SD & Adj p values & $\begin{array}{l}\text { Adj p value } \\
\text { for woun } \\
\text { status }\end{array}$ \\
\hline \multirow[t]{2}{*}{ Wound status } & Healed & Unhealed & & \\
\hline & $74.44 \pm 17.82(31)$ & $64.40 \pm 20.24(87)$ & & \\
\hline Sex & & & $0.00^{*}$ & $0.01^{*}$ \\
\hline Female & $66.88 \pm 16.38(12)$ & $55.65 \pm 19.78(27)$ & & \\
\hline Male & $79.21 \pm 17.40(19)$ & $68.33 \pm 19.34(60)$ & & \\
\hline Age & & & 0.16 & $0.02^{*}$ \\
\hline$\leq 60$ yrs & $76.25 \pm 16.38(16)$ & $61.42 \pm 20.40(58)$ & & \\
\hline$>60$ yrs & $72.5 \pm 19.62(15)$ & $70.35 \pm 18.87(29)$ & & \\
\hline Living status & & & $0.01^{*}$ & $0.01^{*}$ \\
\hline Living alone & $75.00 \pm N A(1)$ & $51.50 \pm 18.49(10)$ & & \\
\hline With children & NA & $61.79 \pm 24.82(7)$ & & \\
\hline With spouse & $83.13 \pm 12.25(12)$ & $72.04 \pm 14.89(27)$ & & \\
\hline With whole family & $68.61 \pm 19.33(18)$ & $63.02 \pm 21.45(43)$ & & \\
\hline \multirow[t]{6}{*}{ Employment } & & & $0.02^{*}$ & $0.01^{*}$ \\
\hline & $77.29 \pm 19.38(12)$ & $73 \cdot 30 \pm 19 \cdot 56(28)$ & & \\
\hline & $74.69 \pm 11.91(8)$ & $63.75 \pm 18.14(22)$ & & \\
\hline & $81.25 \pm 8.84(2)$ & $60.71 \pm 15.99(7)$ & & \\
\hline & $91.25 \pm 5.30(2)$ & $60.56 \pm 20.53(9)$ & & \\
\hline & $62.50 \pm 20.57(7)$ & $56.07 \pm 21.43(21)$ & & \\
\hline
\end{tabular}


Table VIII: (Continued)

\begin{tabular}{|c|c|c|c|c|}
\hline Variables & Mean \pm SD & Mean \pm SD & Adj p values & $\begin{array}{l}\text { Adj p values } \\
\text { for wound } \\
\text { status }\end{array}$ \\
\hline SES_groups & & & 0.85 & $0.02^{*}$ \\
\hline Low & $75.18 \pm 18.44(14)$ & $62.32 \pm 17.95(28)$ & & \\
\hline Medium & $75.63 \pm 14.58(12)$ & $66.30 \pm 22.98(25)$ & & \\
\hline High & $69 \cdot 50 \pm 25 \cdot 58(5)$ & $64.71 \pm 20.34(34)$ & & \\
\hline Education_groups & & & 0.46 & $0.02^{*}$ \\
\hline Upper Primary & $78.18 \pm 18.41(11)$ & $71.04 \pm 22.42(12)$ & & \\
\hline High School & $71.53 \pm 18.23(18)$ & $62.77 \pm 20.50(55)$ & & \\
\hline Higher Secondary & $87.50 \pm N A(1)$ & $65.94 \pm 23.22(8)$ & & \\
\hline Higher education & $72.50 \pm N A(1)$ & $64.17 \pm 15.24(12)$ & & \\
\hline
\end{tabular}

Table VIII shows significant results of two factors ANOVA for Subscale 4 - Emotions score)

Table IX: Results of two factors ANOVA for Subscale 5 - Treatment score, n (118)

\begin{tabular}{|c|c|c|c|c|}
\hline Variables & Mean \pm SD & Mean \pm SD & Adj P values & $\begin{array}{l}\text { Adj P values for } \\
\text { wound status }\end{array}$ \\
\hline \multirow[t]{2}{*}{ Wound status } & Healed & Unhealed & & \\
\hline & $79.03 \pm 12.35(31)$ & $64.66 \pm 15.45(87)$ & & \\
\hline Sex & & & 0.08 & $0.00^{*}$ \\
\hline Female & $79.17 \pm 11.72(12)$ & $59.72 \pm 16.11(27)$ & & \\
\hline Male & $78.95 \pm 13.05(19)$ & $66.88 \pm 14.75(60)$ & & \\
\hline Age & & & 0.45 & $0.00^{*}$ \\
\hline$\leq 60$ yrs & $81.64 \pm 12.39(16)$ & $62.93 \pm 14.99(58)$ & & \\
\hline$>60$ yrs & $76.25 \pm 12.09(15)$ & $68.10 \pm 16.05(29)$ & & \\
\hline SES_groups & & & 0.08 & $0.00^{*}$ \\
\hline Low & $78.13 \pm 14.66(14)$ & $61.38 \pm 15.78(28)$ & & \\
\hline Medium & $79.69 \pm 9.66(12)$ & $63.50 \pm 15 \cdot 59(25)$ & & \\
\hline High & $80.00 \pm 13 \cdot 55(5)$ & $68.20 \pm 14.79(34)$ & & \\
\hline Education_groups & & & $0.01^{*}$ & $0.00^{*}$ \\
\hline Upper Primary & $74 \cdot 43 \pm 11.68(11)$ & $59.38 \pm 18.56(12)$ & & \\
\hline High School & $80.56 \pm 12.11(18)$ & $63.86 \pm 15.76(55)$ & & \\
\hline Higher Secondary & $100.00 \pm N A(1)$ & $78.91 \pm 7.42(8)$ & & \\
\hline Higher education & $81.25 \pm \mathrm{NA}(1)$ & $64.06 \pm 9.28(12)$ & & \\
\hline
\end{tabular}

Table IX shows significant results of two factors ANOVA for Subscale 5 - Treatment score 


\section{DISCUSSION}

Populace based examinations over the world show that the rate of Type 2 diabetes mellitus is expanding among youthful grown-ups. This will prompt an expansion in the predominance of small scale and fullscale neuro-vascular complications associated with diabetes.

According to the international diabetic federation, ${ }^{15}$ Globally, the number of diabetics in 2017 was 427 million and for 2019 was 463 million and the projected value for 2030 is 578 million (10.2\%) and 700 million (10.9\%) in 2045. The pervasiveness of Type 2 diabetes is expanding everywhere throughout the world and about $80 \%$ of individuals with diabetes live in lower economy countries. ${ }^{15}$ Around 2.2 million deaths in 2019 worldwide were attributed to diabetes.

DFU is one of the most feared complications of diabetes mellitus and constitutes a major public health problem due to their negative impact on the quality of life resulting in the overall poor prognosis of the disease. It leads to a long period of hospitalization, morbidity and mortality, thus incur substantial expenditure. ${ }^{6}$

The mean \pm SD old enough in years for rustic diabetic population considered was $57.66 \pm 7.71$. This is like announced from different studies. ${ }^{7}$ Based on the injury status, the patients were gathered into recuperated and unhealed. Two gatherings didn't contrast from one another concerning other segment qualities. Among the 118 patients examined, just 39 (33.1\%) were females. Among patients with a foot ulcer, there is a prevalence of males. This is found in India yet besides in created nations, where nearly everybody with foot ulcer might be accepting foot care. ${ }^{7}$

This affirms our notion that the male prevalence in our example isn't because of any predisposition. Along these lines, this can't be clarified because of predisposition preferring the male in accepting foot care. The male dominance could be ascribed to higher tobacco use and ensuing vascular issues alongside more presentation to open-air occupations. This uncovers youthful male diabetic working populace is at high danger of getting diabetic foot ulcer at an early age. This is consistent with studies by other studies. ${ }^{9}$ the majority of the study population were manual labourers including agricultural workers, carpenters, and drivers. Their knowledge regarding foot care practices and footwear were very minimal. A significant number of patients revealed that they were not taught to take the medicine routinely to keep up great glycemic control. The DFS SF has five subscales to quantify various areas of personal satisfaction, for example, relaxation, physical wellbeing, everyday exercises, feelings and treatment. Wound status as a fundamental indicator of good QOL.

The mean scores for every one of the subscales were essentially unique in the two injury status gathering (mend- ed and unhealed foot ulcer). The same finding has been found in different populaces. Because of the speculation tried, it was presumed that HRQL was reliably higher in the recuperated gathering, significantly after it was balanced for different indicators, for example, sex, ulcer duration. ${ }^{10}$ Various studies have shown that a diabetic foot ulcer patient has a significant impact on people's psychological and emotional QOL particularly in their daily routines, family life and employment opportunities. ${ }^{8} \mathrm{Neg}-$ ligence or under treatment due to the financial crisis is a major roadblock in the treatment and eventually may lead to amputation, which further accentuates the depressive state due to disability. Dominant part detailed that they needed to take early retirement, had a loss of openings for work and needed to change their example work because of the event foot ulcer. This is like the announced examination by Others. ${ }^{11}$ As we expected the effect of diabetic foot ulcer among the youthful working populace was higher than that in the more established working populace. This shows the significance of early mending among youthful diabetics, which will straightforwardly add to increment in national salary. This is predictable with other studies. ${ }^{12}$ Timely intercessions and wellbeing instruction for diabetic foot ulcer centring youthful diabetics will assist with diminishing the general effect of diabetes on the economy, as the predominance of diabetic populace increments alongside youthful working populace.

Out of the 118 patients met 44 (37.3\%) were accounted for that they needed to rely upon some trouble fund component to deal with the disastrous wellbeing spending. Patients with longer length of ulcer end up in calamitous degree of wellbeing spend. Comparative discoveries have been found from India. ${ }^{13}$ Longer-term of ulcer builds the money related weight on the family. This again underscores the early mediation and prevention. ${ }^{14}$

\section{CONCLUSION}

A diabetic foot ulcer is an ignored infection by the patient as well as by the general public and the wellbeing framework. Early recognition and great glycemic control will lessen the frequency of foot ulcer. The DFS SF is a decent scale to gauge the inert variable, HRQL. It has great build legitimacy against SF 36 v2. This scale can be utilized among the country diabetic foot ulcer populace for evaluating the HRQL. The HRQL is identified with the mending of the diabetic foot ulcer. The examination uncovers that injury status is a significant indicator of good HRQL among diabetic foot ulcer patients. The diabetic foot ulcer must be effectively treated so that to forestall crumbling of personal satisfaction. 


\section{ACKNOWLEDGEMENT}

I would like to express my gratitude to my colleagues and institutional authority. A great help received from Dr. Priyadershini Rangari, for data collection and statistics. Thank you for your support. As it was an observational study, very less expenditure was required. So, we did not require any financial support.

\section{Conflict of interest: None}

Source of Funding: None

\section{REFERENCES}

1. Whiting DR, Guariguata L, Weil C, Shaw J. IDF Diabetes Atlas: Global estimates of the prevalence of diabetes for 2011 and 2030. Diabetes Res Clin Pract. 2011; 94(3): 311-21.

2. Rastogi A, Bhansali A. Diabetic foot infection: An Indian scenario. J Foot Ankle Surg (Asia-Pacific) 2016;3:71-9.

3. Bakker K, Apelqvist J, Lipsky BA, Van Netten JJ. International Working Group on the Diabetic Foot. The 2015 IWGDF guidance documents on prevention and management of foot problems in diabetes: Development of an evidence-based global consensus. Diabetes Metab Res Rev. 2016;32(Suppl 1):2-6

4. Seth A, Attri AK, Kataria H, Kochhar S, Seth SA, Gautam N. Clinical Profile and Outcome in Patients of Diabetic Foot Infection. Int J Appl Basic Med Res. 2019;9(1):14-19. doi: 10.4103/ijabmr.IJABMR 278 18. PMID: 30820414; PMCID: PMC6385536.

5. Christos D. Liapis, Klaus Balzer, Fabrizio Benedetti- Valentini. José Fernandes e Fernandes. Diabetic foot. Vascular surgery, Part of the European Manual of Medicine book series. 2002;501-521.

6. Bekele F, Fekadu G, Bekele K, Dugassa D (2019) Incidence of Diabetic Foot Ulcer among Diabetes Mellitus Patients Admit- ted to Nekemte Referral Hospital, Western Ethiopia: Prospective Observational Study. Endocrinol Metab Syndr 8:300.

7. Alosaimi FD, Reem Labani, Nouf Almasoud et al. Associations of foot ulceration with quality of life and psychosocial determinants among patients with diabetes; a case-control study Journal of Foot and Ankle Research (2019) 12:57 https://doi. org/10.1186/s13047-019-0367-5

8. Helen Gilpin, Katie Lagan Quality of life aspects associated with diabetic foot ulcers: A review The Diabetic Foot J. 2008; (11) 2: 10-112.

9. Vaz NC, Ferreira A, Kulkarni M, Vaz FS, Pinto N. Prevalence of diabetic complications in rural Goa, India. Indian J Community Med. 2011; 36(4): 283-6.

10. Serigo Aguinaldo De Almeda, Maika Moura Silveira, Patrica Ferreira Do, Espirito Santo, Rita De Cassia Pereira, Geraldo Magela Salome. Assesment of quality of life of patients with Diabetes Mellitus and Foot Ulcer. Rev Bras Cir Plast 2013; 28(1): 142-6.

11. Jayaprakash P, Bhansali S, Bhansali A, Dutta P, Anantharaman R. Magnitude of foot problems in diabetes in the developing world: a study of 1044 patients. Diabet Med. 2009; 26(9): 939-42.

12. Ramachandran A. Socio-economic burden of diabetes in India. J Assoc Physicians India. 2007; 55(2): 9- 12.

13. Kutty VR, Soman CR, Joseph A, Pisharody R, Vijayakumar $\mathrm{K}$. Type 2 diabetes in southern Kerala: variation in prevalence among geographic divisions within a region. Natl Med J India. 2000; 13(6): 287-92.

14. Thankappan KR, Shah B, Mathur P, Sarma PS, Srinivas G, Mini GK, et al. Risk factor profile for chronic non-communicable diseases: results of a community-based study in Kerala, India. Indian J Med Res. 2010; 131: 53-63.

15. Global and regional diabetes prevalence estimates for 2019 and projections for 2030 and 2045: Results from the International Diabetes Federation Diabetes Atlas, 9th edition. Diabetes research and clinical practice 2019;7(3): 1-10. 